\title{
1993 MRS Spring Meeting
}

\section{San Francisco, California - April 12-16, 1993}

\section{Meeting Chairs: \\ Martin L. Green, AT\&T Bell Laboratories \\ Merrilea J. Mayo, Pennsylvania State University Stephen M. Shapiro, Brookhaven National Laboratory}

Researchers at the 1993 MRS Spring Meeting will continue to add to the growing web of knowledge about materials. About 2,300 abstracts will be packed into 29 symposia on materials, processing, characterization, and theory of electronic and optical materials, polymers, biomaterials, superconductors, fullerenes, ferroelectric materials, magnetic materials, rocks and ceramics, and hosts of other materials.

A large portion of the meeting will consider materials issues in electronics and optoelectronics, ranging from surface cleaning to device performance. Fundamentals such as thermodynamics, kinetics, and mechanical properties will be covered, as well as applications-oriented topics such as amorphous silicon, II-VI photovoltaic materials, infrared and radiation detectors, and reliability issues.

Developments on light emission from porous silicon will join a new symposium covering silicon-based optoelectronic ma- terials, which includes SiGe quantum wells, nanoparticles, and Er-doped silicon.

As traditional optical lithography reaches its resolution limits, $x$-ray lithography is a possible route to making finer features. Researchers will cover the latest developments on masks, resists, $x$-ray sources, and $\mathrm{x}$-ray optics. $\mathrm{X}$-rays are also featured in a symposium on synchrotron radiation techniques, used to probe almost every type of material.

Infrared detectors made from compound semiconductors, $\mathrm{HgCdTe}, \mathrm{Si}$, silicides, $\mathrm{Pb}$ salts, and novel materials fills one symposium. Another symposium covers materials used for room-temperature radiation detectors and applications of these materials in medicine, space, robotics and even in the verification of nuclear materials in international safeguards.

A panel discussion Tuesday evening will highlight late-breaking results on giant magnetoresistance in magnetic alloy thin films. Will these materials offer a simple route to magnetic devices?

The symposium on theory is taking a broad approach by having joint sessions with other symposia on magnetic multilayers, giant magnetoresistance, and mechanics of epitaxial layers. In addition, the symposium presenters are starting the week with an issues-oriented session, given by Praveen Chaudhari from IBM, who will look generally at MS\&E policy, and then will specifically target opportunities in theory.

Polymers take their place in the meeting with a cluster of three symposia covering polymer/inorganic interfaces, high-performance polymers and polymer matrix composites, and organic materials for nonlinear optics.

A new symposium will look at the difficult problem of joining advanced inorganic materials, such as ceramic to ceramic, and metal to ceramic. Techniques to solve this problem include diffusion bonding, microwave and laser joining, soldering, and novel welding techniques. Fundamentals of adhesion, bonding, mechanical stress, and interfacial thermodynamics establish the foundation for a deeper understanding of this field.

Geologists and ceramists will seek common ground in a symposium on deformation and failure in rocks and ceramics, examining brittle fracture, superplasticity, and densification.

There will be ample opportunity to bone up on hydroxyapatite, the principal inorganic constituent in hard tissue. In addition to its role in osteoporosis and tooth decay, hydroxyapatite exhibits interesting properties for coatings, catalysis, and other applications.

For a complete list of technical symposia and session titles, see the matrix on the following pages.

\section{Special Features}

Plenary Presentation and Awards Ceremony. The Plenary speaker Tuesday evening will be Craig R. Barrett, the chief operating officer of Intel Corporation. Barrett joined Intel in 1974, and has held a variety of positions, from reliability and quality assurance to components technology. The Outstanding Young Investigator Award and the Graduate Student Awards will be given immediately before the plenary presentation. Following Barrett's presentation, a reception will be held at the Equipment Exhibit. The winner of the Outstanding Young Investigator Award will give a special talk on Tuesday at noon.

Materials Manufacturing Forum. A forum at noon on Thursday will examine the role materials research can play in manufacturing. Representatives from government, industry, and national laboratories will address the challenge of designing materials for ease of manufacturing, transferring technology from the lab to the factory, and converting defenserelated materials and technologies to commercial enterprises.

Education Session. For people interested in contributing to $\mathrm{K}-12$ science education, there will be a Grass Roots Education Session Monday, at noon. Speakers from the Science Carnival Project, Sandia National Laboratories in Livermore, and from the Lawrence Hall of Science in Berkeley will demonstrate handson activities that scientists or teachers can do with students. This session will be complemented-on Monday by an evening poster session displaying science activities.

Authoritative Reviews. Symposium X, lunchtime authoritative reviews for nonspecialists, will cover topics represented by the technical symposia, plus two talks on Wednesday covering environmental con- cerns that relate to materials science. Deanna Richards from the National Academy of Engineering will talk about "Evolving Materials Use and the Environment." David Allen from the University of California-Los Angeles will discuss, "Wastes as Raw Materials."

Other Events. The meeting also will have short courses and tutorials related to symposium topics, an extensive equipment exhibit, a job placement bulletin board, three evenings of poster sessions, a student mixer, and other auxiliary events. For further details about the meeting, see the 1993 MRS Spring Meeting Program, which will be mailed to all MRS members. If you need a program or would like to register, call or fax the MRS Meetings Department.

Phone: (412) 367-3003

Fax: (412) 367-4373 


\begin{tabular}{|c|c|c|c|c|c|c|c|}
\hline \multirow{2}{*}{ Activity } & \multirow{2}{*}{ Location } & \multicolumn{3}{|c|}{ Monday, April 12} & \multicolumn{3}{|c|}{ Tuesday, April 13} \\
\hline & & a.m. & p.m. & eve $^{\star}$ & a.m. & p.m. & eve \\
\hline $\begin{array}{l}\text { A. Amorphous Silicon } \\
\text { Technology-1993 }\end{array}$ & $\begin{array}{l}\text { Marina } \\
\mathrm{D} / \mathrm{E} / \mathrm{F}\end{array}$ & & & & $\begin{array}{l}\text { A1: Defects: Charge States and } \\
\text { Relaxation } \\
\text { A2: Plasmas and Film Growth } \\
\end{array}$ & $\begin{array}{l}\text { A3: Solar Cells } \\
\text { A4: Defects Light-and } \\
\text { Current-Induced }\end{array}$ & \\
\hline $\begin{array}{l}\text { B. Silicon-Based } \\
\text { Optoelectronic } \\
\text { Materials }\end{array}$ & $\underset{B / C}{\text { Marina }}$ & $\begin{array}{l}\text { B1: SiGe I } \\
\text { B2: SiGe II }\end{array}$ & $\begin{array}{l}\text { B3: SiGe III } \\
\text { B4: Nanoparticles }\end{array}$ & B5: Posters & $\begin{array}{l}\text { B6: Porous Silicon: } \\
\text { Chemistry/Fabrication I } \\
\text { B7: Porous Slicon: } \\
\text { Chemistry/Fabrication II }\end{array}$ & B8/E2: Rare Earth Doped Slicon & \\
\hline $\begin{array}{l}\text { C1. II-VII Compound } \\
\text { Semiconductor Photovoltaic } \\
\text { Technology }\end{array}$ & $\underset{J}{\text { Pacific }}$ & C1-1: CulnSe $e_{2}$ : Materials Growth & $\begin{array}{l}\text { C1-2: CulnSe, : Materials } \\
\text { Characterization. }\end{array}$ & & $\begin{array}{l}\text { C1-3: CoTe: Materials Growth and } \\
\text { Characterization }\end{array}$ & & \\
\hline $\begin{array}{l}\text { C2. Infrared Delectors - } \\
\text { Materials, Processing } \\
\text { and Devices }\end{array}$ & $\begin{array}{l}\text { Check } \\
\text { Schedule }\end{array}$ & & & & & & \\
\hline $\begin{array}{l}\text { D1. III-V Electronic and } \\
\text { Photonic Device Fabrication } \\
\text { and Performance }\end{array}$ & $\begin{array}{l}\text { Salon } \\
\text { C1 }\end{array}$ & D1-1: HbTS/HEMTS & D1-2: Dry Etching and Deposition & D1-3: Posters & $\begin{array}{c}\text { D1-4: Contact Metallization and } \\
\text { Passivation }\end{array}$ & 101-5: Lasers and Heterojunctions & \\
\hline $\begin{array}{l}\text { D2. Low-Temperature-Grown and } \\
\text { Highly Non-Stoichiometric } \\
\text { GaAs and Related Materials }\end{array}$ & $\begin{array}{c}\text { Salon } \\
\text { B3 }\end{array}$ & D2-1: Growth Issues & $\begin{array}{l}\text { D2-2: Processing and } \\
\text { Characterization }\end{array}$ & & $\begin{array}{c}\text { D2-3: Optical and Optoelectronic } \\
\text { Properties }\end{array}$ & $\begin{array}{l}\text { D2-4: InP and Related Ternary } \\
\text { Materials } \\
\text { O2.5 : Applications of } \\
\text { Non-Stoichiometric Materials }\end{array}$ & \\
\hline $\begin{array}{l}\text { E. Rare-Earth Doped } \\
\text { Semiconductors }\end{array}$ & $\begin{array}{c}\text { Sunset } \\
\text { B }\end{array}$ & & & & E1: Rare Earth Incorporation & $\begin{array}{c}\text { E2/B8: Rare Earth Doped Slicon } \\
\text { Marina B/C }\end{array}$ & \\
\hline $\begin{array}{l}\text { F. Semiconductors tor } \\
\text { Room-Temperature } \\
\text { Radiation Detectlor Applications }\end{array}$ & $\begin{array}{l}\text { Sunset } \\
\mathrm{E} / \mathrm{F}\end{array}$ & $\begin{array}{l}\text { F1: Materials, Devices and } \\
\text { Applications I }\end{array}$ & $\begin{array}{l}\text { F2: Materials, Devices and } \\
\text { Applications II }\end{array}$ & & F3: Mercuric lodide & F4: Cadmium Telluride & \\
\hline $\begin{array}{l}\text { G. Rapid Thermal and } \\
\text { Integrated Processing }\end{array}$ & $\begin{array}{c}\text { Salon } \\
\text { B1 }\end{array}$ & $\begin{array}{l}\text { G1: Rapid Thermal CVD of } \\
\text { Semiconductors and Dielectrics }\end{array}$ & G2: Silicides and Barriers & & $\begin{array}{l}\text { G3: Temperature Measurement } \\
\text { for RTP } \\
\text { G4: RTP Equipment Issues and } \\
\text { Modeling }\end{array}$ & $\begin{array}{l}\text { 64: RTP Equipment lssues and } \\
\text { Modeling (cont.) }\end{array}$ & \\
\hline $\begin{array}{l}\text { H. Polymer/ } \\
\text { Inorganic Interfaces }\end{array}$ & $\underset{\mathrm{A}}{\mathrm{Marina}}$ & & & & & & \\
\hline $\begin{array}{l}\text { 1. High.-Pertormance } \\
\text { Polymers and Polymer } \\
\text { Matrix Composites }\end{array}$ & $\begin{array}{c}\text { Sunset } \\
0\end{array}$ & & & & & $\begin{array}{l}\text { I1: High Temperature Polymers } \\
\text { and Composites }\end{array}$ & \\
\hline $\begin{array}{l}\text { J. Organic Materials for } \\
\text { Nonlinear Optical Applications }\end{array}$ & $\begin{array}{c}\text { Sunset } \\
C\end{array}$ & & & & & & \\
\hline $\begin{array}{l}\text { K. Materials Aspects of X-Ray } \\
\text { Lithography }\end{array}$ & $\begin{array}{l}\text { Sunset } \\
C\end{array}$ & K1: X-Ray Lithography & K2: X-Ray Masks I & & K3: Muttilayer X-Ray Optics & K4: X-Ray Technology & \\
\hline $\begin{array}{l}\text { L. Applications of Synchrotron } \\
\text { Radiation Techniques to } \\
\text { Materials Science }\end{array}$ & $\begin{array}{c}\text { Salon } \\
\text { A3 }\end{array}$ & L1: Topography and Tomography & $\begin{array}{c}\text { L2/01-1///22.2: Applications of } \\
\text { Synchrotron Radiation } \\
\text { Techniques to Magnetic Materials } \\
\text { Nob/Russian/Petrero/Telegraph } \\
\text { Hill }\end{array}$ & L3: Posters & $\begin{array}{l}\text { L4: EXAFS-Fundamentals and } \\
\text { Appliations }\end{array}$ & L5: Novel Materials & \\
\hline $\begin{array}{l}\text { M1. Thin Films - } \\
\text { Stresses and Mechanical } \\
\text { Properties IV }\end{array}$ & $\begin{array}{l}\text { Salon } \\
\text { C2 }\end{array}$ & M1-1: Stresses in Thin Films & $\begin{array}{l}\text { M1-2: Measuring Stresses and } \\
\text { Mechanical Properties-New } \\
\text { Techniques and Developments }\end{array}$ & M1-3: Posters & $\begin{array}{c}\text { M1-4/M2-4. Stress, } \\
\text { Electromigration and Voiding in } \\
\text { Fine Line Structures }\end{array}$ & $\begin{array}{l}\text { M1-5M2-5. Stress Relaxation } \\
\text { Mechanisms and Thin Film } \\
\text { Morphology }\end{array}$ & $\begin{array}{c}\text { Group Discussion } \\
\text { Salon C2 }\end{array}$ \\
\hline $\begin{array}{l}\text { M2. Materials Reliability } \\
\text { in Microelectronics III }\end{array}$ & $\begin{array}{l}\text { Salon } \\
\text { C3 }\end{array}$ & M2-1: Dielectric Reliability, Oxides & $\begin{array}{l}\text { M2-2: Microstructure Effects on } \\
\text { Reliability: Electromigration in } \\
\text { Fine Lines }\end{array}$ & M2-3: Posters & \begin{tabular}{|c|} 
M2-4/M1-4: Stress. \\
Electromigration and Voiding in \\
Fine Line Structures \\
Salon C2
\end{tabular} & $\begin{array}{l}\text { M2.5/M1-5. Stress Reliaxation } \\
\text { Mechanisms and Thin Film } \\
\text { Morphology } \\
\text { Salon C2 }\end{array}$ & \\
\hline $\begin{array}{l}\text { N. Ferroelectric } \\
\text { Thin Films III }\end{array}$ & $\begin{array}{l}\text { Nob Hill } \\
\text { Russian Hill }\end{array}$ & & & & & $\begin{array}{l}\text { N1: Novel Characterization } \\
\text { N2: Device Materials Science }\end{array}$ & \\
\hline $\begin{array}{l}\text { 0. Phase Iranstormations in } \\
\text { Thin Films - Thermo- } \\
\text { dynamics and Kinetics } \\
\end{array}$ & $\begin{array}{l}\text { Salon } \\
\text { A2 }\end{array}$ & & & & $\begin{array}{l}\text { 01: Stress Eftects } \\
\text { 02: Crystallization }\end{array}$ & 03. Silicides & \\
\hline $\begin{array}{l}\text { P. Common Themes and } \\
\text { Mechanissms of } \\
\text { Epitaxial Growth }\end{array}$ & Presidio & & & & & $\begin{array}{l}\text { P1: Plenary } \\
\text { P2: Roughening }\end{array}$ & \\
\hline $\begin{array}{l}\text { 01. Magnetic Ultrathin } \\
\text { Films. Multilayers } \\
\text { and Surfaces }\end{array}$ & $\begin{array}{l}\text { Petrero Hill/ } \\
\text { Telegraph Hill }\end{array}$ & & $\begin{array}{c}\text { Q1-1//02-2/2:2: Applications of } \\
\text { Synchrotron Radiation } \\
\text { Techniques to Magnetic Materials } \\
\text { Nob/Russian/Pentrero/Telegraph } \\
\text { Hill }\end{array}$ & & $\begin{array}{l}\text { 01-2N3: Magnetic Mutiliayers: } \\
\text { Theory }\end{array}$ & $\begin{array}{l}\text { Q1.3/W4: Giant } \\
\text { Magnetoresistance in Multilayers } \\
\text { Role of Interface Structure }\end{array}$ & $\begin{array}{l}\text { Q1-4: Giant } \\
\text { Magnetoresistanc } \\
\text { in Alloys: A } \\
\text { Simple Route to } \\
\text { Magnetic } \\
\text { Devices? }\end{array}$ \\
\hline $\begin{array}{l}\text { 02. Magnetic Interriaces - } \\
\text { Physics and } \\
\text { Characterization }\end{array}$ & $\begin{array}{c}\text { Check } \\
\text { Schedule }\end{array}$ & $\begin{array}{l}\text { 02-1: Theories and Spin Polarized } \\
\text { Spectroscopies } \\
\text { Pettrero Hill/Telegraph Hill }\end{array}$ & $\begin{array}{l}\text { 02-2/.2/2/1-1: Applications of } \\
\text { Synchrotron Radiation } \\
\text { Tecchniques to Magnetic Materials } \\
\text { Nob/Russian/Petrero/Relegraph }\end{array}$ & & $\begin{array}{l}\text { 02-3: Structural and Interfacial } \\
\text { Characterization } \\
\text { Nob rili//Russian Hill }\end{array}$ & $\begin{array}{l}\text { 02-4: Nanostructural } \\
\text { Characterization } \\
\text { Sunset B }\end{array}$ & \\
\hline $\begin{array}{l}\text { R. Joining and Adhesion } \\
\text { of Advanced } \\
\text { Inorganic Materials }\end{array}$ & $\underset{A}{\text { Marina }}$ & & $\begin{array}{l}\text { R1: Mechanical Properties and } \\
\text { Stress States in Joints }\end{array}$ & & $\begin{array}{l}\text { R2: Diffusion Bonding } \\
\text { R3: Microwave and Laser Joining }\end{array}$ & $\begin{array}{l}\text { R4: Advanced and Novel Joining } \\
\text { Techniques }\end{array}$ & \\
\hline $\begin{array}{l}\text { S. Fullerenes and } \\
\text { Related Materials }\end{array}$ & $\underset{H}{\text { Pacific }}$ & & S1: Nanotubes I & & S2: Nanotubes II & S3: Optics and Superconductivity & \\
\hline $\begin{array}{l}\text { T. Materials Issues in } \\
\text { High-Temperature } \\
\text { Superconductivity }\end{array}$ & $\begin{array}{l}\text { Salon } \\
\text { B2 }\end{array}$ & $\begin{array}{l}\text { T1. Flux Pinning and Cintical } \\
\text { Currents }\end{array}$ & $\begin{array}{l}\text { T2: Wires and Tapes: Phase and } \\
\text { Microstructure Evolution }\end{array}$ & T3: Posters & $\begin{array}{c}\text { T4: Wires and Tapes: } \\
\text { Electromagnetic and Mechanical } \\
\text { Properties } \\
\text { T5: Thick Films } \\
\end{array}$ & T6: Conductor Development & \\
\hline $\begin{array}{l}\text { U. Mechanisms of Deformation } \\
\text { and Failure in } \\
\text { Rocks and Ceramics }\end{array}$ & $\begin{array}{l}\text { Pacific } \\
1\end{array}$ & & $\begin{array}{l}\text { U1: Fracture Processes in Rocks } \\
\text { and Ceramics I }\end{array}$ & U2: Posters & $\begin{array}{l}\text { U3: Fracture Processes in Rocks } \\
\text { and Ceramics II }\end{array}$ & $\begin{array}{l}\text { U4: Plasticity. Compaction and } \\
\text { Stress-Induced Iransformations } \\
\text { in Rocks and Ceramics }\end{array}$ & \\
\hline $\begin{array}{l}\text { V. Hydroxyapatite } \\
\text { and Related } \\
\text { Compounds }\end{array}$ & $\begin{array}{c}\text { Sunset } \\
\mathrm{A}\end{array}$ & & & & V1: Crystal Chemistry of Apatites & $\begin{array}{l}\text { 12: Innovative Processes to Form } \\
\text { Apattes }\end{array}$ & \\
\hline $\begin{array}{l}\text { W. Theory of } \\
\text { Materials Properties }\end{array}$ & $\begin{array}{l}\text { Check } \\
\text { Schedule }\end{array}$ & $\begin{array}{l}\text { W1: Issues and Topics in } \\
\text { Materials Theory } \\
\text { Marina D/E/F }\end{array}$ & $\begin{array}{l}\text { W2: Fracture } \\
\text { Marina D/E/F }\end{array}$ & & $\begin{array}{c}\text { W3/01-2: Magnetic Muttilayers: } \\
\text { Pheory } \\
\text { Petrero/Telegraph Hill }\end{array}$ & $\begin{array}{l}\text { W4/01-3: Giant } \\
\text { Magnetoresistance in Muttilayers } \\
\text { Role of Interface Structure } \\
\text { Pettrero/Relegraph Hill }\end{array}$ & \\
\hline$\chi$. Frontiers of Materials Research & Presidio & & $x-1$ & & & $x-2$ & \\
\hline $\begin{array}{l}\text { Y. Surface Chemical Cleansing } \\
\text { and Passivation for } \\
\text { Semiconductor Processing }\end{array}$ & $\begin{array}{l}\text { Salon } \\
\text { A1 }\end{array}$ & & & & $\begin{array}{c}\text { Y1: Slicon Water Cleaning and } \\
\text { Particle Considerations } \\
\text { Y2: Surface Chemical and } \\
\text { Morphological Control and } \\
\text { Gate-Oxidation }\end{array}$ & $\begin{array}{c}\text { Y3: Deposition I: Silicon Epitaxy } \\
\text { Y4: Deposition II: Non-Silicon } \\
\text { Materials }\end{array}$ & \\
\hline
\end{tabular}


Wednesday, April 14

a.m.

A5: Hydrogen Dynamics

a6: New Deposition Approaches

B9: Porous Slicon: Optical

B10: Porous Slicon: Optical Properties II C2-1: IR Detectors Based on III.
Materials

p.m.

A7: Detectors. Sensors and

A8: Narrow Bandgap Alloys B11: Applications/Electroluminesence B12: Wrap-Up

\section{C2-3: HgCoTe Materials and Devices}

C2-1: IR Detectors Based on III.V C2-3: HgCoTe Materials and Materials IR Materials Charac

1-6: Ion Implantation

C2.3: HgCole Materials and
Devices
Pacific J

D1-7/G7: RTA/RTP and Integrated Processing
Thursday, April 15

m. m.

p.m.

Friday, April 16

a.m.

A15: Electrical Transport

A10: Wide Bandgap Alloys A12: Electronic Characterization A14: Posters A11: Thin Film Transistors A13: New Materials and Devices

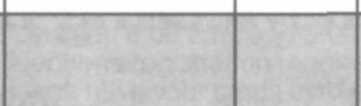

Technology (A)

\section{C2-4/F8: II-VI Detector}

Technology (A)

Technology $(B)$

C2-6: Posters

Sunset $E / F$

01-8: Point Defects and Diffusion

C2-5/F9: II-VI Detector

C2-6: Posters

D1.8. Point Defects and Diftusion

A16: Mainly Metastability

C2-7: IR Detectors Based on Si

Silicides, Pb Salts, and Novel Materials

2-7: IR Detectors Based on Si

Slicicides, Pb Salts and Novel Sunset B

E4: Excitation Mechanisms

E5: Posters
Sunset B

E6: Novel Structures and Devices

E7: Theory and Models

F10: Silicon Technology F5: Diamond

F6: New Detector Materials

\begin{tabular}{c|c}
$\begin{array}{c}\text { F8/C2.4: II.VI Detector } \\
\text { Technology (A) }\end{array}$ & $\begin{array}{c}\text { F9/C2-5: II-VI Detector } \\
\text { Technology (B) }\end{array}$
\end{tabular}

\section{5: Rapid Thermal Annealing Ninidation}

HIII:

Sunset D

$12 / \mathrm{H} 1$

G7/D1.7: RTA/RTP and integrated Processing

Salon C1

H2: Interface Properties and Durability

13: Processing and Characterization

J1: Crystals and Unusual Materials

K5: X-Ray Masks II

Salon B3

L6: X-Ray Scattering

7: Electronic and $\mathrm{Hi}-\mathrm{I}_{c}$ Materials

LB: X-Ray and VUV Methods

J2: Molecular Materials

(2)

ar Materials

1.6/W5: Mechanics and licrostructure in Epitaxial Layers

12-6: 1/f Noise, Resistance Drift. Microstructure and

M1.7: Mechanical Behavior of Polymer Coatings

M2-7: Microstructure and Electromigration in $\mathrm{Al}, \mathrm{Cu}$ and Al-Alloy Thin Films

N3: Optoelectronic Devices and
Properties

N5: Degradation/Modelling N6: Characterization of

4. Process Integration

Ferroelectric Thin Film Electrode Intertaces

04: Solid-State Amorphization 05: Film Growth

P3: Composition and Strain

P4: Posters/Balliroom Lobby

Q1.5: Interlayer Coupling I

Q1-6: Interlayer Coupling II Multilayers I

\section{R5: Joining and Adhesion in \\ R6. Novel Braze/Solder Materials}

S4: Superconductivity and Structure

77: Grain Boundary Micro)Structures and Properties

U5: Stress Corrosion, Surface Processes and Superplasticity in Rocks and Ceramics

V3: Crystallization Phenomena

W5/M1-6: Mechanics and Microstructure in Epitaxial Layers Salon C2

06: Irradiation Effects

P5: Surface Chemistry

F7: Posters

\section{8: Novel Processes and Applications}

H3: Metal/Polymer Interfaces

H4: Fundamentals of Polymer/Surface Interface H5: Surface Modification

\begin{tabular}{l|l} 
14: Interfaces and Fibers & 15: Aging and Degradation
\end{tabular}

J3: Polymers

\section{L9: Surfaces, Interfaces, Thin} Films and Multilayers

\begin{tabular}{|l|}
\hline \\
\hline \\
\hline
\end{tabular}

$+2$

11-8. Mechanical Deformation of

M1-8: Mechanical Deforma
Thin Films

J4: Polymers and Calculations

M2-8. Corrosion and Diffusion

Related Reliability Issues

\begin{tabular}{l|c|c} 
N7: Chemical Vapor Deposition & N9: Niobium and Barium Based \\
N8: Spin Pyrolysis of Thin Films & $\begin{array}{c}\text { N10: Posters } \\
\text { N11: Posters }\end{array}$
\end{tabular}

10: Microscopy/Microprobe and
Photoabsorption
L11: Microscopy/Microprobe and
Photoabsorption

M1-9: Fracture. Adhesion and M-10: Posters Wear of Thin Films

08: Interfacial Reactions N11: Poster Preview

07: Posters

Interfacia Reactions

\begin{tabular}{|l|c|}
\hline & $\begin{array}{c}\text { P6: Coalescence and Step Flow } \\
\text { P7: Posters } \\
\text { Ballioom Lobby }\end{array}$ \\
\hline 1 & Q1-8: Structure and Magnetism I
\end{tabular}

P8: Surface Structure

P8: Surtace Stucture

in

in

: Structure and Magnetism II Multilayers and Spin Valves I

01-11: Posters

Q1-12: Posters

\section{Q1-14: Magnetic Bilayers, \\ Tnilayers and Multilayers \\ Magneto-Optics} and Bonding

tynamics

S5: Chemistry, Physics, and Polymers

T8: Grain-Boundary Junctions T9: Thin Films

U6: High Temperature
Mechanisms of Deformation in

Rocks and Ceramics

V4: Coatings

Bone-Hydroxyapatie
Interactions |

W6: Phase Stability !

Salon B3

X.3

$Y 7$ : Metal Contamination

Y8: Metal Contamination II
R7: Fundamentals of Adhesion

\begin{tabular}{|l|l|}
\hline & \\
\hline & \\
\hline
\end{tabular}

\begin{tabular}{l|}
\hline S7: Synthesis and Surfaces \\
\hline $\begin{array}{c}\text { T11: YBCO Junctions with } \\
\text { Artificial Barriers }\end{array}$
\end{tabular}

\begin{tabular}{|c|}
\hline S8: Endohedrals and Complexes \\
\hline T12: RF Properties
\end{tabular}

S9: Endohedrals and Complexe: Sunset A

T14: Junctions Development

\section{V6: Bone-Hydroxyapatite $\quad$ V8: Advanced Characterization}

77: Interactions II
S6: Posters

M1-11: The Mechanical

N12: Sputter Deposition Vapor Deposition Techniques

Hydroxapatite-Organic

W7: Phase Stability II

Salon B3

Y9: Posters $\quad$ Y10: Oxides/nterfaces/Surfaces 触 $\mathrm{F}_{2} \mathrm{O}$ Cleaning and

Passivation I 


\section{MRS SPRING MEETING General Meeting Information}

\section{Location/Lodging}

San Francisco Marriott Hotel

55 Fourth Street

San Francisco, CA 94103

(800) 228-9290 Nationwide • (415) 896-1600 Direct

Fax (415) 442-0141

\section{DEADLINE FOR HOTEL RESERVATIONS March 15, 1993}

A block of rooms has been reserved for MRS meeting attendees at the San Francisco Marriott Hotel (30 minutes from the San Francisco International Airport). When making your reservations, mention the Materials Research Society to receive the special rates of $\$ 120 /$ single and $\$ 140 /$ double, plus California and local taxes.

\section{Local Transportation}

The San Francisco Airporter service between the airport and downtown San Francisco hotels is $\$ 8$ one way, or $\$ 14$ round trip. Cab fares are approximately $\$ 28$.

\section{Parking}

Parking at the San Francisco Marriott is $\$ 24$ per day (valet only). Public parking is available within easy walking distance of the hotel at an average cost of $\$ 10$ for 24 hours.

\section{Travel Arrangements}

The official travel management company for the Materials Research Society's 1993 Spring Meeting is Giselle's Travel Bureau, formerly Travel Bureau of Sacramento. They will guarantee the lowest fares on any airline at time of booking. Call and ask for MRS Group 001: 1-800-782-5545

Monday-Friday • 7:30 a.m.-5:30 p.m. PST

or

$$
\text { Fax: (916) 924-0474 or 1-800-TRVLFAX }
$$

For alternative housing information, you may contact Giselle's Travel Bureau by calling the above number.

MRS meeting attendees receive the following travel benefits and services:

- Lowest fares on any airline guaranteed - Free flight insurance of $\$ 500,000$ - Computerized driving instructions from major U.S. airports $\bullet$ Car rental savings $\bullet$ Vouchers for discounts on vacation packages

ONE MRS 1993 SPRING MEETING ATTENDEE WILL WIN TWO (2) FREE AIRLINE TICKETS TO ANYWHERE IN THE 48 CONTIGUOUS STATES. To be eligible: You, your travel agent, or your in-house travel department must make your reservations through Giselle's Travel Bureau by calling the above phone number.

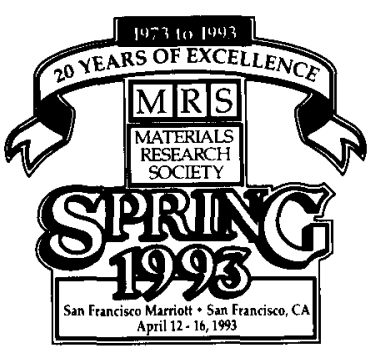

\section{Short \\ Course \\ and}

Tutorial

Program

\section{Characterization of Materials}

C-07 Amorphous Silicon Materials and Devices for Large Area Electronics

instructors: Robert A. Street and Michael G. Hack, Xerox Palo Alto Research Center

C-28 IC Failure Analysis: Failure Mechanisms and Characterization Techniques

New! Instructors: Giorgio Riga, Riga Analytical Laboratory and Alton D. Romig, Jr., Sandia National Laboratories „an pemonstrations:

C-29 Practical Electron Diffraction

New! Instructor: Ronald M. Anderson, IBM Corporation

\section{Preparation and Fabrication of Materials}

P-02 Molecular Beam Epitaxy

Instructor: L. Ralph Dawson, Sandia National Laboratories

P-10 Metalorganic Chemical Vapor Deposition and Atomic Layer Epitaxy

Instructor: Robert Biefeld, Sandia National Laboratories

P-14 Film Formation, Adhesion, Surface Preparation and Characterization of Thin Film Structures Instructor: Donald M. Mattox, IP Industries

P-23 Excimer Laser Ablation and Etching of Materials Instructor: James Brannon, IBM Almaden Research Center
Techniques

T-05 Plasma Technology for Thin Film Deposition Instructor: Donald M. Mattox, IP Industries

Advanced Materials

M-11 Magnetic Thin Films: Physics and Applications Instructors: Ernesto E. Marinero and Virgil S. Speriosa. IBM Almaden Research Center

\section{M-16 Ferroelectric Thin Films}

Instructors: Angus I. Kingon, North Carolina State University, and Seshu Desu, Virginia Polytechnique Institute and State University

$$
\bullet \bullet \bullet \bullet
$$

\section{Tutorial Program}

MRS Tutorials are designed to inform individuals about subjects that are outside their immediate interest or to bring individuals "up to speed" in an area that they have recently entered.

TP-3 Fullerenes

Instructors: Peter C. Eklund, University of Kentucky, and Gene Dresselhaus, MIT

TP-4 Organic and Polymeric Materials for Optoelectronics New! Instructors: Robert J. Twieg, IBM Almaden Research Center, and Carl Dirk, University of Texas at EI Paso

$\bullet \bullet \bullet \bullet$

\section{On-Site Short Course Program}

These courses are available on a contract basis for presentation at your facility, subject to instructor availability. For further details, contact Vivienne Harwood Mattox, MRS Short Course Manager.

Telephone (505) 294-9532; Fax (505) 298-7942

\section{Registration Information}

To request details of the program, information about student scholarships, or special short course and meeting registration discounts, contact:

Materials Research Society, 9800 McKnight Road, Pittsburgh, PA 15237

Telephone (412) 367-3003; Fax (412) 367-4373 


\section{BY MAIL}

Return this form with payment to:

Materials Research Society

Meeting Registration

9800 McKnight Road

Pittsburgh, PA 15237

\section{TELEPHONE}

Call the MRS Meeting Registration Desk

(412) 367-3003 between 8:00 a.m. and 5:00 p.m.

Eastern time. Telephone registration requires

credit card payment; have your credit card and

this form in front of you for easy reference.

\section{FAX}

Transmit this order form via Fax to the

MRS Meeting Registration Desk (412) $367-4373,24$ hours a day. Fax registration requires credit card payment.

\section{PREREGISTRATION DEADLINE: APRIL 2, 1993}

NOTE: Please enter MRS code from mailing label ( 0 ...). If this is not your own copy, ente the code from the label and check here. $\square$

If you do not have a mailing label code, draw a Enter mailing label code in box. line through code box.

Please fill in form completely and legibly to assure proper processing. Name

Title. First/Middle Initial

Department

Institution

Address

City

State/Province Zip/Postal Code

Country

Telephone

E-Mail:

$$
\text { (Network \& Address) }
$$

This address is: $\square$ Business $\square$ Home $\square$ Address Change

$\square$ MRS selectively permits use of its membership list by advertisers of products which the Society deems to be of high interest to MRS members. Please check here if you do not wish to receive these mailings.

\section{A MEETING PREREGISTRATION \\ Please check category and enter amount in payment section below.}

$\square \$ 240$ Member

$\square 275$ Nonmember

$\square \$ 65$ Student Member

$\square$ \$75 Student Nonmember *

$\square \$ 95$ Short Course attendee registered for at least two course days

Meeting registration includes complimentary half-year MRS membership beginning July 1, 1993.

"Student must provide proof of full-time student status at time of submission of registration, i.e. class schedule with your name or signed letter from your faculty advisor or registrar. Symposium interest (please check all that apply):

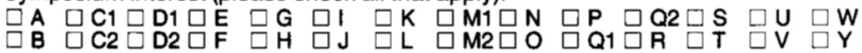

TUIAL $\$$

Enter total here and in box below right.

\section{BJOURNAL OF MATERIALS RESEARCH 1993}

Subscription at Member Rate (one per registrant)

$\square \$ 45=$ TOTAL

Enter total here and in box at right. (published after this meeting)

PROCEEDINGS

These rates apply only to meeting and short course attendees, and MRS members. Nonmembers must contact MRS headquarters for prices.

Amorphous Si

Si-Based Optoelectronics.

o. Copies

Infrared Detectors

III-V Electronic/Photonic Devices

Rare-Earth Semiconductors. .

Semiconductors for Radiation Detection.

Rapid Thermal/Integrated Processing . .

Polymer/Inorganic Interfaces . .

Polymers/Polymer Matrix Composites

X-Ray Lithography

Synchrotron Radiation . .

Thin Film

Materials Reliability

Ferroelectric Thin Films

Phase Transformations.

Epitaxial Growth

Q1/Q2. Magnetic Materials.

Joining of Inorganic Materials.

$\mathrm{Y}$ Cleaning/Passivation for Semiconductors
$\$ 48 x$

$\$ 45$

$\$ 40 x$

$\$ 45 x$

$\$ 45 x$

$\$ 47 x$

$\$ 45 x$

$\$ 43 x$

$\$ 47 x$

$\$ 48 \mathrm{x}$

$\$ 48 x$

$\$ 48 x$

$\$ 48 x$

$\$ 48 x$

$\$ 48 x$

$\$ 48 x$

$\$ 55 x$

$\$ 43 x$

$\$ 48 \times$

Sub-Total

6\% Sales Tax (PA residents only)

TOTAL PROCEEDINGS

\section{DSHORT COURSES}

To preregister, check each course in which you wish to enroll. If you register for two or more course days, you may attend the technical meeting for only $\$ 95$; just complete the Meeting Preregistration section at left.

Facilities registering three or more persons at the same time in one MRS Short Course receive a $20 \%$ discount for the third and all additional persons.

At-meeting short course registrations will be $\$ 25$ higher for each course.

Cancellations received by Âpril 2, 1993, will be refunded less a service

charge of $\$ 25$. There is no charge if you wish to transfer to another course.

$\square$ C-07 Amorphous Silicon Materials and Devices

C-28 IC Failure Analysis

C-29 Practical Electron Diffraction

P-02 Molecular Beam Epitaxy

$\square$ P-10 MOCVD and Atomic Layer Epitaxy

P-14 Film Formation, Adhesion, Surface Preparation . . . . . . . . . . . . \$595

- P-23 Excimer Laser Ablation and Etching of Materials . . . . . . . . . \$195

M-11 Magnetic Thin Films.................. \$595

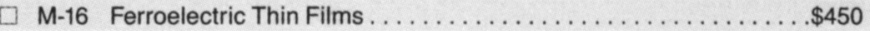

T-05 Plasma Technology for Thin Film Deposition . . . . . . . . . . . . . . \$395

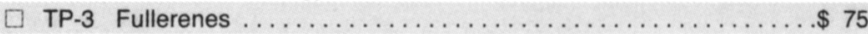

TP-4 Organic/Polymeric Materials for Optoelectronics ............ \$ 75

Combined Course Tuition

$\square$ P-10 and P-02: total fee is $\$ 595$

Any combination of P-14, P-23, and T-05 that results in 1.5, 2.5, 3, and 3.5 course days: $\$ 495, \$ 695, \$ 795$, and $\$ 895$, respectively.

TOTAL SHORT COURSE TUITION \$

Enter total here and in box below.

\section{PAYMENT OPTIONS}

$\square$ Payment is enclosed. Make checks payable, in U.S. dollars, to Materials Research Society. Payment from outside the U.S. should be drawn on a correspondent U.S. bank.

Credit card payment: $\square$ Visa $\square$ MasterCard $\square$ Diners Club $\square$ AmEx

Card number

Expiration date

Signature

Registrations received without payment or credit card authorization will be invoiced the at-meeting rates.
A. Meeting preregistration fee (from left)
B. Journal of Materials Research (from left)
C. Proceedings (from left)
D. Short courses (from above)

TOTAL FEES PAID

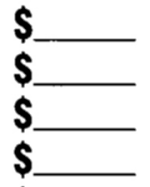

\section{S}

If you are unemployed or retired and are a current or former member of MRS, or recent graduate not yet employed, reduced registration rates are available. To learn if you are eligble, contact the MRS Meetings Department via mail, phone, or fax (numbers are listed at the top of this form).

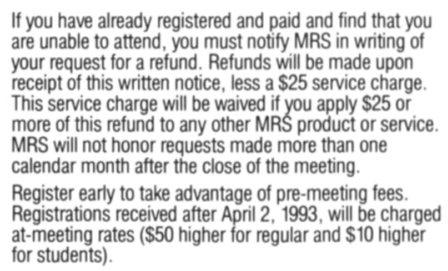
For Accounting Use Only Check\#

Date Batch\# Total Type 


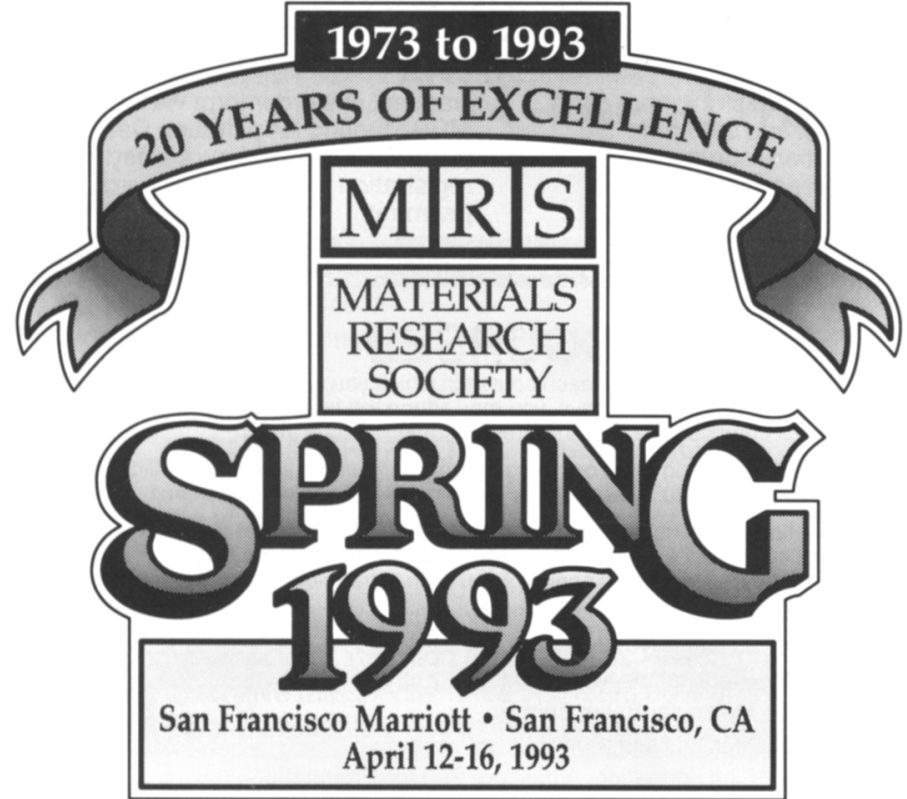

TECHNICAL PROGRAM

A: Amorphous Silicon Technology - 1993

B: Silicon-Based Optoelectronic Materials

C1: II-VI Compound Semiconductor Photovoltaic Technology

C2: Infrared Detectors - Materials, Processing and Devices

D1: III-V Electronic and Photonic Device Fabrication and Performance

D2: Low-Temperature-Grown and Highly Non-Stoichiometric GaAs and Related Materials

E: Rare-Earth Doped Semiconductors

F: Semiconductors for Room-Temperature Radiation Detector Applications

G: Rapid Thermal and Integrated Processing

$\mathrm{H}$ : Polymer/Inorganic Interfaces

I: High-Performance Polymers and Polymer Matrix Composites

J: Organic Materials for Nonlinear Optical Applications

K: Materials Aspects of X-Ray Lithography

L: Applications of Synchrotron Radiation Techniques to Materials Science

M1: Thin Films - Stresses and Mechanical Properties IV

M2: Materials Reliability in Microelectronics III

$\mathrm{N}$ : Ferroelectric Thin Films III

$\mathrm{O}$ : Phase Transformations in Thin Films - Thermodynamics and Kinetics

P: Common Themes and Mechanisms of Epitaxial Growth

Q1: Magnetic Uitrathin Films, Multilayers and Surfaces

Q2: Magnetic Interfaces - Physics and Characterization

R: Joining and Adhesion of Advanced Inorganic Materiais

S: Fullerenes and Related Materials

T: Materials Issues in High-Temperature Superconductivity

U: Mechanisms of Deformation and Failure in Rocks and Ceramics

V: Hydroxyapatite and Related Compounds

W: Theory of Materials Properties

$X$ : Frontiers of Materials Research

Y: Surface Chemical Cleaning and Passivation for Semiconductor Processing

\section{- New Materials Development - New Characterization Methods - New Process Technology}

\section{SYMPOSIUM AIDE OPPORTUNITIES}

Graduate students who plan to attend the MRS Spring Meeting and are willing to assist in the symposium presentations can earn a waiver of the student registration fee and MRS student half-year membership by applying for Symposium Aide positions.

\section{EQUIPMENT EXHIBIT}

A major exhibit of the latest analytical and processing equipment which closely parallels the nature of the technical symposia will be located in the Yerba Buena Ballroom, San Francisco Marriott Hotel, convenient to the technical session rooms. For show booth information, contact: Bob Finnegan, MRS Show Manager, American Institute of Physics, 335 East 45th Street, New York, NY 10017; Telephone (212) 661-9404; FAX (212) 661-2036

\section{SHORT COURSE PROGRAM}

Courses on advanced materials characterization, preparation, and processing/diagnostic techniques have been designed for scientists, engineers, managers, and technical staff who wish to update their knowledge and skills in the research, development and processing of materials. These up-to-date courses are at the forefront of science and technology and complement Spring Meeting symposia. Class sizes are limited. Early preregistration is encouraged.

\section{PROCEEDINGS}

Many of the MRS symposia will be publishing proceedings. For a complete list of MRS publications and prices, contact Materials Research Society, Publications Department, 9800 McKnight Road, Pittsburgh, PA. 15237; Telephone (412) 367-3012; FAX (412) 367-4373

\section{PREREGISTRATION}

Preregister by telephone, (412) 367-3003, or FAX (412) 367-4373, with your VISA, MasterCard, Diners Club, or AmEx card. Ask for Meeting Registration and your preregistration will be completed for you. Telephone preregistrations are accepted between 8:00 a.m. and 5:00 p.m. EST, Monday through Friday. Confirmations will be mailed within 10 working days.

\section{$\mathrm{M} \mid \mathrm{R} S$}

Materials Research Society

9800 McKnight Road, Pittsburgh, PA 15237

Telephone (412) 367-3003; FAX (412) 367-4373

The 1993 MRS Spring Meeting will serve as a key forum for discussion of interdisciplinary leading-edge materials research from around the world. Various meeting formats - oral, poster, roundtable, forum and workshop sessions - are offered to maximize participation. 


\section{EQUIPMENT EXHIBIT}

\section{San Francisco Marriott Hotel Yerba Buena Room Tuesday-Thursday - April 13-15, 1993}

As part of the 1993 Spring Meeting, a major equipment exhibit will be held to display analytical and processing equipment closely paralleling the nature of the technical symposia. The technical program has been arranged to allow meeting participants ample opportunity to visit the exhibit.

\begin{tabular}{|c|}
\hline Exhibit Hours \\
\hline 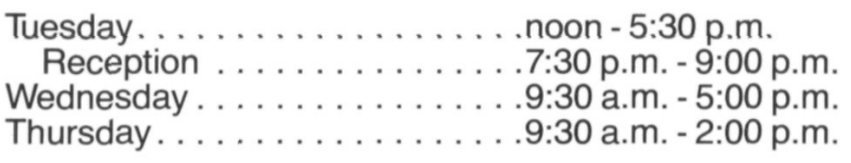 \\
\hline $\begin{array}{l}\text { Coffee will be available during morning and afternoon } \\
\text { breaks in the Equipment Exhibit area, Tuesday after- } \\
\text { noon through Thursday morning. }\end{array}$ \\
\hline
\end{tabular}

\section{Partial List of 1993 Spring Equipment Exhibitors}

Academic Press, Inc.

Advanced Technology Materials, Inc.

Aixtron, Inc.

American Institute of Physics

Anatech, Ltd.

APD Cryogenics Inc.

Applied Science \&

Technology, Inc.

Biosym Technologies

Blake Industries, Inc.

Butterworth-Heinemann

Denton Vacuum, Inc.

Duniway Stockroom Corp.

Elsevier Science Publishing Company, Inc.

Emcore Corporation

EPI

Charles Evans \& Associates

FEI Company

E.A. Fischione Instruments, Inc.
Fisons Instruments

Gatan, Inc.

Granville-Phillips Company

IBM Analytical Services

Intevac MBE

Ion Tech, Inc.

IOP Publishing

JEOL U.S.A., Inc.

Keithley Instruments

Kluwer Academic Publishers

Lake Shore Cryotronics

Kurt J. Lesker Company

MDC Vacuum Products Corp.

Molecular Simulations Inc.

Nano Instruments, Inc.

National Electrostatics Corporation

North Eastern Analytical Corporation

Omicron Associates

Peabody Scientific Instruments

Pergamon Press, Inc.
Perkin-Elmer Corporation

Plasma-Therm I.P., Inc.

Pure Tech Inc.

Quantum Design, Inc.

Radiant Technologies, Inc.

Research and PVD Materials Corp.

South Bay Technology, Inc.

STAIB Instrumente GmbH

Structure Probe/SPI Supplies

Superior Vacuum Technology

Surface/Interface Inc.

Technical Instrument Company

Tencor Instruments

TopoMetrix

VAT, Inc.

VCR Group, Inc.

Virginia Semiconductor, Inc.

Voltaix, Inc.

Companies interested in exhibiting may contact:

Bob Finnegan, MRS Equipment Exhibit Manager

American Institute of Physics

335 East 45th Street, New York, NY 10017

Telephone (212) 661-9404 • Fax (212) 661-2036

See ad in this issue. 
Place your order now for proceedings from the 1993 MRS Spring Meeting in San Francisco and save an average of $20 \%$ off regular member prices.

SPECIAL PRE-MEETING PRICES EFFECTIVE UNTIL MAY 15, 1993.

(After that, pay the higher price on the right.)

MRS Members, Spring Meeting and Short Course attendees are eligible for member prices.

A: Amorphous Silicon Technology - 1993

Editors: E.A. Schiff, M.J. Thompson,

P.G. LeComber, A. Madan, K. Tanaka

ISBN: 1-55899-193-X

Code: 297-B

\$48 \$65 MRS Members

$\$ 65 \$ 75$ U.S. Lisi

$\$ 70 \$ 80$ Foreign

B: Silicon-Based Optoelectronic Materials

Editors: R.T. Collins, M.A. Tischler,

G. Abstreiter, M.L. Thewalt

ISBN: 1-55899-194-8 Code: 298-B

\$45 \$55 MRS Members

$\$ 55$ \$65 U.S. List

$\$ 60$ \$70 Foreign

C2: Infrared Detectors - Materials,

Processing, and Devices

Editors: A. Appelbaum, L.R. Dawson

ISBN: 1-55899-195-6

Code: 299-B

$\$ 40 \$ 50$ MRS Members

$\$ 50$ \$60 U.S. List

\$55 \$65 Foreign

D1: III-V Electronic and Photonic Device

Fabrication and Performance

Editors: K.S. Jones, S.J. Pearton, H. Kanber

ISBN: 1-55899-196-4 Code: 300-B

$\$ 45 \$ 55$ MRS Members

$\$ 55$ \$65 U.S. List

$\$ 60$ \$70 Foreign

E: Rare-Earth Doped Semiconductors

Editors: G.S. Pomrenke, P.B. Klein,

D.W. Langer

ISBN: 1-55899-197-2 Code: 301-B

\$45 \$55 MRS Members

$\$ 55$ \$65 U.S. List

$\$ 60 \$ 70$ Foreign

F: Semiconductors for Room-Temperature

Radiation Detector Applications

Editors: R.B. James, P. Siffert,

T.E. Schlesinger, L. Franks

ISBN: 1-55899-198-0

Code: $302-B$

$\$ 47 \$ 57$ MRS Members

$\$ 57 \$ 67$ U.S. List

$\$ 62 \$ 72$ Foreign

G: Rapid Thermal and Integrated

Processing II

Editors: J.C. Gelpey, J.K. Elliott,

J.J. Wortman, A. Ajmera

ISBN: 1-55899-199-9

Code: 303-B

$\$ 45 \$ 55$ MRS Members

$\$ 55$ \$65 U.S. List

$\$ 60$ \$70 Foreign
H: Polymer/Inorganic Interfaces

Editors: R.L. Opila, A.W. Czanderna,

F. J. Boerio

ISBN: 1-55899-200-6

Code: 304-B

$\$ 43 \$ 53$ MRS Members

$\$ 53$ \$63 U.S. List

\$58 \$68 Foreign

I: High-Performance Polymers and Polymer Matrix Composites

Editors: R.K. Eby, R.C. Evers, D. Wilson,

M.A. Meador

ISBN: 1-55899-201-4 Code: 305-B

\$47 \$57 MRS Members

\$57 \$67 U.S. List

$\$ 62 \$ 72$ Foreign

K: Materials Aspects of X-Ray Lithography Editors: G.K. Celler, J.R. Maldonado

ISBN: 1-55899-202-2 Code: 306-B

$\$ 48$ \$62 MRS Members

$\$ 62$ \$72 U.S. List

$\$ 72 \$ 77$ Foreign

L: Applications of Synchrotron Radiation

Techniques to Materials Science

Editors: D.L. Perry, R. Stockbauer, N. Shinn,

K. D'Amico, L. Terminello

ISBN: 1-55899-203-0

Code: 307-B

$\$ 48 \$ 62$ MRS Members

$\$ 62 \$ 72$ U.S. List

$\$ 67$ \$77 Foreign

M1: Thin Films - Stresses and Mechanical

Properties IV

Editors: P.H. Townsend, J. Sanchez, C-Y. Li,

T.P. Weihs

ISBN: 1-55899-204-9 Code: 308-B

$\$ 48$ \$62 MRS Members

$\$ 62 \$ 72$ U.S. List

$\$ 67 \$ 77$ Foreign

M2: Materials Reliability in

Microelectronics III

Editors: K. Rodbell, B. Filter, P. Ho, H. Frost

ISBN: 1-55899-205-7 Code: 309-B

$\$ 48 \$ 62$ MRS Members

$\$ 62$ \$72 U.S. List

$\$ 67$ \$77 Foreign

N: Ferroelectric Thin Films III

Editors: E.R. Myers, B.A. Tuttle, S.B. Desu,

P.K. Larsen

ISBN: 1-55899-206-5

Code: 310-B

\$48 \$58 MRS Members

$\$ 58$ \$68 U.S. List

$\$ 63$ \$73 Foreign
O: Phase Transformations in Thin Films -

Thermodynamics and Kinetics

Editors: M. Atzmon, J.M.E. Harper,

A.L. Greer, M.R. Libera

ISBN: 1-55899-207-3

Code: 311-B

$\$ 48 \$ 62$ MRS Members

$\$ 62$ \$72 U.S. List

$\$ 67 \$ 77$ Foreign

P: Common Themes and Mechanisms of Epitaxial Growth

Editors: P. Fuoss, J. Tsao, D.W. Kisker,

A. Zangwill, T.F. Kuech

ISBN: 1-55899-208-1

Code: 312-B

\$48 \$62 MRS Members

$\$ 62 \$ 72$ U.S. List

$\$ 67$ \$77 Foreign

Q1/Q2: Magnetic Ultrathin Films,

Multilayers and Surfaces/ Magnetic

Interfaces - Physics and Characterization

(2 Volume Set)

Editors: C. Chappert, R.F.C. Farrow,

B.T. Jonker, R. Clarke, P. Grünberg,

K.M. Krishnan, S. Tsunashima/

E.E. Marinero, T. Egami, C. Rau,

S.A. Chambers

ISBN: 1-55899-211-1

Code: $313-\mathrm{B}$

\$55 \$68 MRS Members

$\$ 68$ \$78 U.S. List

$\$ 72$ \$82 Foreign

R: Joining and Adhesion of Advanced Inorganic Materials

Editors: A.H. Carim, D.S. Schwartz,

R.S. Silberglitt, R.E. Loehman

ISBN: 1-55899-212-X

\$43 \$53 MRS Members

$\$ 53$ \$63 U.S. List

\$58 \$68 Foreign

Y: Surface Chemical Cleaning and

Passivation for Semiconductor Processing

Editors: G.S. Higashi, E.A. Irene, T. Ohmi

ISBN: 1-55899-213-8

\$48 \$58 MRS Members

$\$ 58$ \$68 U.S. List

$\$ 63$ \$73 Foreign

\section{TO ORDER CONTACT}

MATERIALS RESEARCH SOCIETY

9800 McKnight Road, Pittsburgh, PA 15237 (412) 36\%-3012; FAX (412) 367-4373.

IN EUROPE, AFRICA \& THE MIDDLE EAST: Clarke Associates - Europe Ltd.

13a Small Street, Bristol BS1 1DE, England 0272 268864, FAX 0272226437 